\title{
PERFORMANCE OF RRBS IN INDIA
}

\author{
Ganesh Bhat H L, \\ Lecturer in Commerce \\ L.B.A.S. \& S.B.S.C. College, \\ SAGAR
}

\begin{abstract}
After nationalization, the Indian banking sector expanded in breadth and scope at a rate perhaps unmatched by any other country. In Indian banking has been remarkably successful at achieving mass participation. RRB's were conceived with notion of augmenting the outreach of the institutional channel of credit in the remotest corner of rural India. The RRB's have got equal status with commercial banks in cash reserves, finance and interest rate. The present paper has the following objectives such as; to study the concept and genesis of RRBs; to list out the sources of rural credit and role of rural credit for RRBs; to address the some emerging issues of $R R B s$ and at the end to offers suggestions for strengthening of RRBs. This research article is based on secondary sources like annual reports of RRBs, NABARD, RBI, journals, books and websites. The data collected were analyzed with the help of statistical technique like, percentages, growth rates etc.
\end{abstract}

Key Words: Regional Rural Banks (RRBs), Development Financial Institutions (DFIs), Securitization and Reconstruction of Financial Assets and Enforcement of Security Interest Act (SARFAESI), Non-Residential External (NRE),Foreign Currency Non-Resident (FCNR-B)

\section{PRELUDE}

In the era of economic reforms and globalization of Indian Economy, the agriculture and rural banking cannot be left in isolation. In India, agriculture should be viable because 70 per cent people are still dependent on agriculture. During last century the financial performance of Regional Rural Banks (RRBs) have changed a lot. To complete with the changing scenario, it is imperative on our part to build up a strong database in respect of rural development banks, as these banks are backbone of the agriculture and rural development in India.

\section{THE PROBLEM}

Rural population of the country constitutes $80 \%$ of population of the country. Most of rural people are facing the problem of poverty, unemployment, regional imbalances the main cause for these problems is non-availability of finance. Both agriculturists and non- agriculturists in rural area require finance for undertaking any activity. But fulfilling their requirement of adequate, cheap and timely fiancé is one of the problems for rural people. In past, the co-operatives and money lenders were the only source of finance for the rural people. Later the credit requirement of rural sector grew multifold, as co-operatives alone would not be able to fulfill the burgeoning demand of rural credit. Therefore after establishing of regional rural banks, it would be a model financial infrastructure for rural development with patronage and encouragement given by planners in the field. Thus, the state sponsored, regionally based and rural-oriented commercial banks have taken birth in rural India which is popularly known as 'Regional Rural Banks'. These banks penetrate every corner of the country and have been extending a helping hand in the growth of the economy. Now, these regional rural banks providing many types of (Loans) 


\section{ELK}

Asia Pacific Journals

credits to cater to the needs of rural people. In these circumstances, a study on "Role of RRBs in rural credit" is keenly felt.

\section{LITERATURE REVIEW}

Numerous research as well as general studies has been conducted over the years with regard to the role of rural banking institutions in financing agriculture, small scale industries and other schemes under the programme of rural development. Having observed the pertinent need for rural credit of RRBs in India, an attempt is made to review the major studies on Regional Rural Banks.

Ravi.N.Kadam. (2007) ${ }^{1}$,, in his paper on Evolution of Rural Banking in India and Its Future thought that, institutional and non-institutional sources of rural credit and help the farmers and rural sector in meeting their financial requirements. The importance of noninstitutional source of credit is declining because of the development and popularity of institutional sources in rural India.

Venkatanaidu.G. $(2012)^{2}$., in his article on Performance of Regional Rural Banks, he identified RRBs today face number of impediments in their holistic growth. The foremost being the pro-poor (rural /poor man's bank) image of RRBs. Public still perceives these banks as only for poor or rural people. Some people assume them to be private banks and desist from having banking relation with RRBs. Not only this, the confinement to local aspect has narrowed down the vision and experience of the RRBs staff resulting in their little development. Thus, there is decisive need to allow the RRBs to grow out and face the realities of the world.

\section{Prabakkar Rajkumar.}

K. $(2007)^{3}$., his study on Financial Performance of RRBs: An Overview opined that during 2003-05 the profit earnings of RRBs have increased by 6 percent and their profit earnings also increased to 168.33 crores. While the loss by RRBs has decreased by 25 percent its loss also reduced to ` 60.19 crores during the periods. The recovery performance of RRBs have increased from 73.49percent to 79.85 percent. It is also observed that the level of NPA is low. The overall analysis shows that, the financial performance of RRBs is at the satisfactory level.

\section{FOCUS OF THE STUDY}

1. To study the concept and genesis of RRBs,

2. To list out the sources of rural credit and role of rural credit in RRBs.

3. To focus on the role of RRBs in the form of agency -wise ground level credit flow, region-wise working results, frequency distribution of states according to levels of recovery, indicators of performance etc..

4. To offers suggestions for strengthening the RRBs.

\section{SOURCE OF DATA AND METHODOLOGY}

The data for the study was collected from the secondary sources such as collected from the annual reports of RRBs, NABARD, RBI, journals, books and websites. The data collected were analyzed with the help of statistical technique such as percentages, growth rates etc.

\section{PERFORMANCE OF RRBs:}

The performance of RRBs from 2009-10 onwards is discussed below.

1. Agency -Wise Ground Level Credit Flow

Table 2: Agency -Wise Ground Level Credit Flow Of Rrbs 


\section{ELK}

Asia Pacific Journals

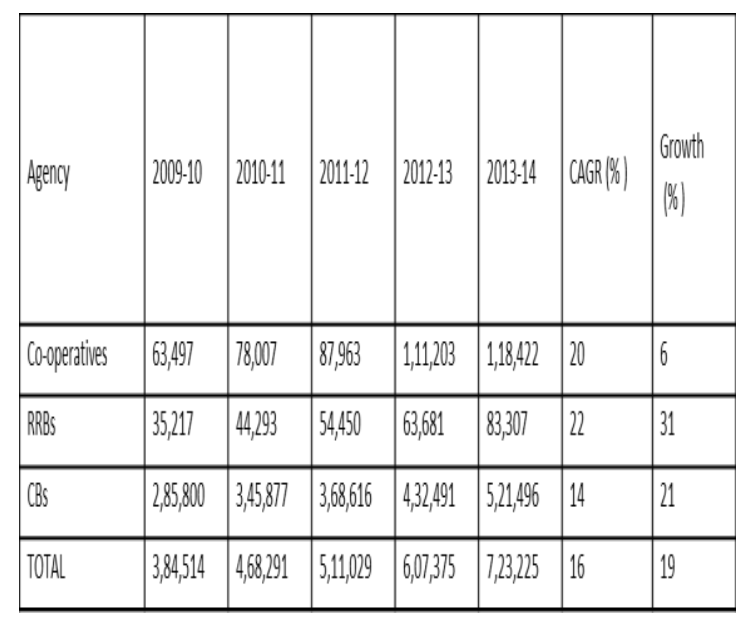

Source: NABARD Annual Report, 200911 to $13-14$

Analysis: As against the target of Rs.7,00,000 crore of credit flow to agriculture sector for 2013-14, the banking system has disbursed Rs.7,23,225 crores (provisional) as on $31^{\text {st }}$ March 2014, achieving 103 per cent of the target. Commercial Banks, Co-operative Banks and Regional Rural Banks (RRBs) have disbursed Rs.5,21,496 crores, Rs.1,18,422 crores and Rs.83,307 crores against their respective targets of Rs.4,75,000 crores, Rs.1,25,000 crores and Rs.1,00,000 crores. The achievements in respect of Commercial Banks Co-operative Banks and RRBs were in the order of 110 per cent, 95 per cent and 83 per cent, respectively.

Analysis: Table 3 shows the financial results of RRBs for the year 2012-13 indicate that there were improvements in their performance, with 63 out of 64 RRBs showing profit to the extent of Rs. 2,384.59 crores as compared to 79 (out of 82 RRBs) with profit of Rs. 1,886.15 crores in 2011-12. The remaining one RRB incurred a loss of Rs. 2.07 crores as compared to loss of Rs. 28.87 crores posted by three RRBs in 2011-12. The number of sustainably viable RRBs i.e., RRBs making net current profit and having no accumulated losses stood at 53
ELK Asia Pacific Journals - Special Issue ISBN: 978-81-930411-0-9

(out of 64 RRBs) as on $31^{\text {st }}$ March 2012. The aggregate reserves of RRBs increased to Rs. 13,130.01 crores and net worth increased to Rs. 18,292.07 crores as on $31^{\text {st }}$ March 2013. There were 11 RRBs with accumulated losses and their accumulated losses had decreased by 24 per cent over the previous year. The performance of RRBs varied across the regions in 2012-13. While all RRBs in the Central Region (16), Eastern(10), Northern (11), Southern (14) and Western (5) earned profit and 7 (out of 8) in North-Eastern region were (earned) in profit. The provisional financial results of RRBs for the year 2013-14, indicates that all 57 RRBs have earned profits aggregating Rs.2,833 crores as compared to 63 out of 64 RRBs earning aggregate profit of Rs.2,275 crores in 2012-13. The proportion of RRBs that are sustainably viable viz., earning profits and carrying no accumulated losses has increased from 83 per cent (53 out of 64 RRBs) as on 31 March 2013 to 86 per cent (49 out of 57) as on 31 March 2014. The aggregate reserves of RRBs increased to Rs.15,736 crores and net worth increased to Rs.21,199 crores as on $31^{\text {st }}$ March 2014. There were 8 RRBs with accumulated losses and their accumulated losses had decreased by 17 per cent over the previous year.

Table 3: Region-Wise Working Results Of Rrbs 
(As On 31 March 2013)

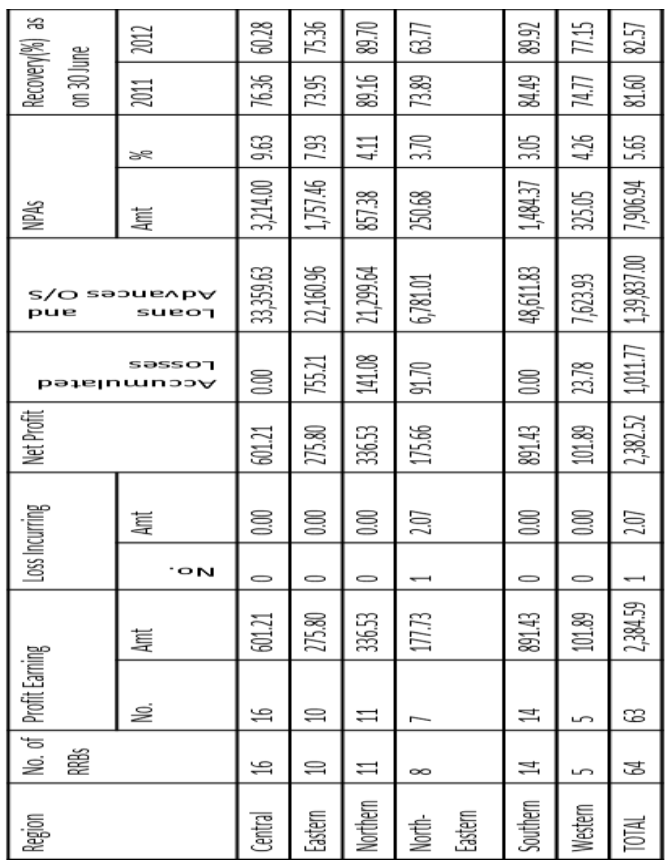

Source: NABARD Annual Report,200911 to $13-14$.

4. Frequency Distribution of States According to Levels of Recovery of RRBs

Table 4: Levels of Recovery of RRBs

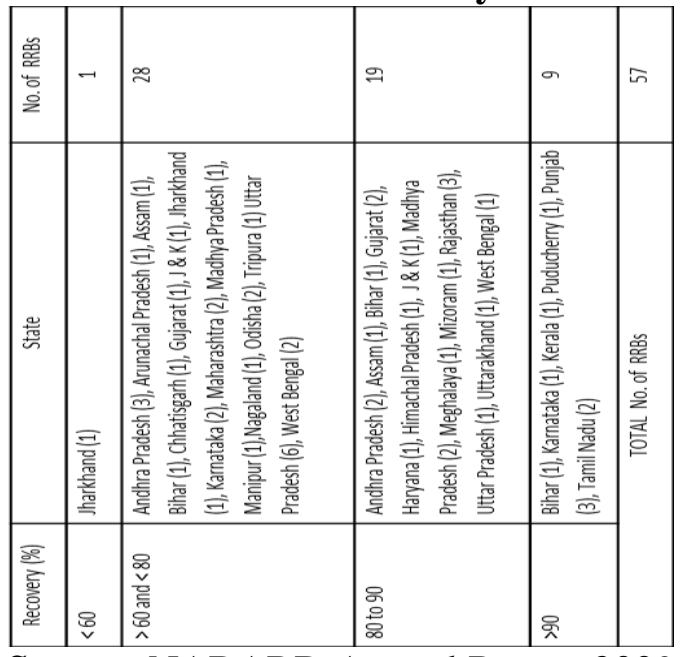

Source: NABARD Annual Report,2009-

11 to $13-14$

The recovery performance of RRBs improved marginally from 81.2 per cent as on $30^{\text {th }}$ June 2012 to 81.9 per cent as on $30^{\text {th }}$ June 2013. Nine RRBs had recovery of more than 90 per cent, 19 RRBs had recovery in the range of 80 to 90 per cent,
28 RRBs had recovery in the range of 60 and 80 per cent and one RRB had recovery of less than 60 per cent (Table 2.19). The aggregate gross NPA of all RRB declined from 6.1 per cent as on $31^{\text {st }}$ March 2013 to 4.4 per cent as on $31^{\text {st }}$ March 2014.

Indicators of Performance:

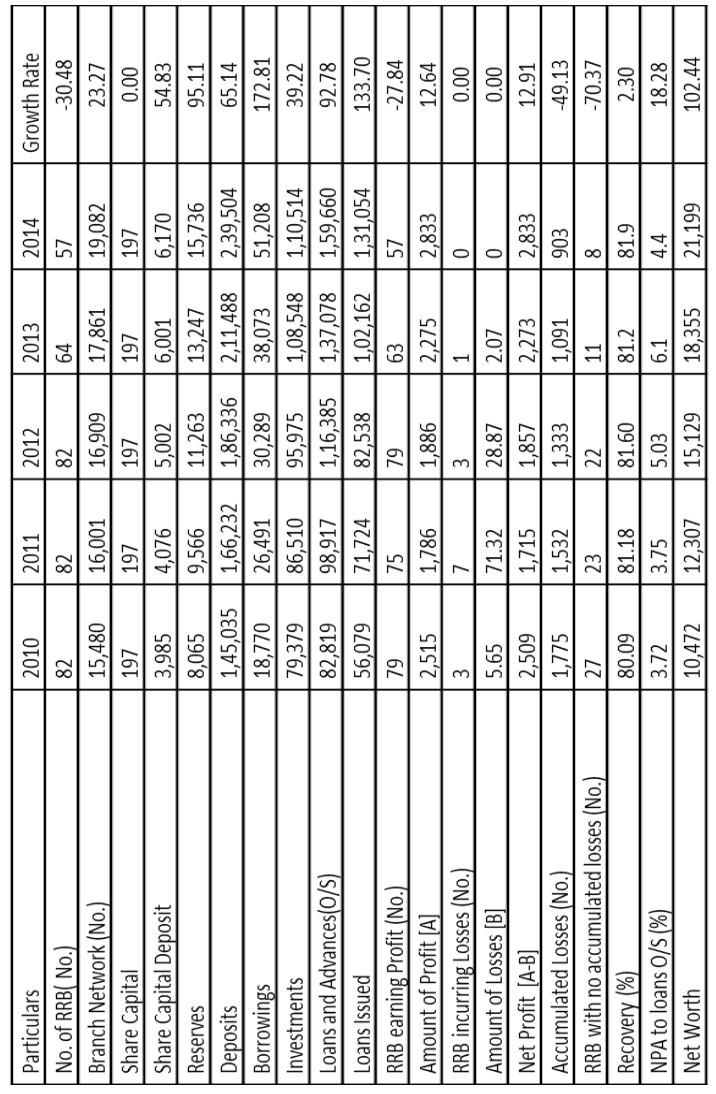

Source: NABARD Annual Report,200911 to $13-14$.

\section{Analysis:}

1. Afteramalgamation, the number of RRBs in the country as on $31^{\text {st }}$ March 2014 stood at 57, with a network of 19,082 branches covering 642 notified districts in 26 States and the UT of Puducherry.

2. The aggregate deposits of RRBs registered a growth of 13 per cent, borrowings 34 per cent, loans and advances (outstanding) 17 per cent and investments 2 per cent, respectively.

3. The decreasing in profit making banks is due to merger of RRBs. 
4. The negative growth rate in case of accumulated loss is a health trend as far as RRBs is concerned.

5. In all the other parameters, the GR is positive, which shows the fairly well performance of RRBs, particularly after merger.

\section{PROBLEMS OF RRBs:}

Although RRBs had a rapid expansion of branch network and increase in volume of business, these institutions went through a very difficult evolutionary process due to the following problems.

1. Limited operational/ service area.

2. High risk due to exposure only to the target group.

3. Mounting losses due to non-viable level of operations in branches located at resource poor areas.

4. Switch over to narrow investment banking as a turnover strategy.

5. Heavy reliance on sponsor banks for investment avenues with low returns.

6. Chairman of RRBs under the direction of regional managers appointed as board of directors by sponsor banks.

7. Unionized staff with low commitment to profit orientation and functional efficiency.

8. Inadequate skills in treasury management for profit orientation.

9. Inadequate exposure and skills to innovate products limiting the lending portfolios.

10. Inadequate effort to achieve desired levels of excellence in staff competence of managing the affairs and business independent entity.

\section{SUGGESTIONS:}

1. RRBs may join in consortium finance with public sector banks/ Development Financial Institutions (DFIs).

2. Securitization and Reconstruction of Financial Assets and Enforcement of
Security Interest Act (SARFAESI), 2002 may be extended to RRBs.

3. The Bank may consider that the NPAs should be avoided in initial stages of credit consideration by putting in place appropriate credit appraisal mechanism.

4. The bank may take steps to constitute more legal cells and tribunals, recovery branches, NPA management departments, Lok Adalats etc., for speedy recovery of NPAs in addition to the existing methods.

5. RRBs may be allowed to deal in NonResidential External (NRE) accounts/ Foreign Currency Non-Resident (FCNR-B) deposits, certificates of deposits, among others, in consortium with sponsor bank and be given the freedom to place their money in term deposits with any bank.

6. Measures should be initiated to deploy credit to various potential and productive sectors, so that the credit deployment raises in proportion to deposits.

\section{CONCLUSION:}

RRBs today face number of impediments in their holistic growth. The foremost being the pro-poor (rural/ poor man's bank) image of RRBs. Public still perceives these banks as 'only for poor or rural people'. Some people assume them to private banks and desist from having banking relations with the RRBs. Not only this, the confinement to local aspects has narrowed down the vision and experience of the RRBs staff resulting in their little development. Thus, there is decisive need to allow the RRBs to grow out and face the realities of the world.

\section{REFERENCES}

[1] Ravi. N. Kadam (2007)., Evolution of Rural Banking in India and Its Future, 


\section{ELK}

Asia Pacific Journals

Southern Economist, July 1, 46 (5), pp. $15-16$

[2] Venkatanaidu.G.(2012)., Performance of Regional Rural Banks, Southern Economist, October 15, 51 (12) PP. 912.

[3] Prabakkar Rajkumar. K.(2007)., Financial Performance of RRBs: An
ELK Asia Pacific Journals - Special Issue ISBN: 978-81-930411-0-9

Overview, Southern Economist, June15, 46 (4), pp. 33-34.

[4] Naqi Uddin (2003)., Regional Rural Banks and Development, Mittal Publications, New Delhi, p.27.

[5] NABARD Annual Report,2009-11 to 13-14.

[6] www.rbi.com

[7] www.rrb.com 